\title{
Karakteristik Morfologi Polong Beberapa Genotipe Kedelai (Glycine max L.Merill)
}

\author{
Nabbu Julia Bule Logo ${ }^{1}$, Siti Zubaidah ${ }^{2}$, Heru Kuswantoro ${ }^{3}$ \\ ${ }^{1}$ Program Studi Pendidikan Biologi, Pascasarjana, Universitas Negeri Malang \\ 2 Jurusan Biologi, FMIPA, Universitas Negeri Malang \\ ${ }^{3}$ Balai Penelitian Tanaman Aneka Kacang dan Umbi (BALITKABI) Malang \\ email: nabbujulia 0407@gmail.com
}

\begin{abstract}
Abstrak
Polong merupakan salah satu organ penting tanaman kedelai karena di dalam polong berisi biji kedelai untuk proses perkembangbiakan kedelai. Struktur kulit polong yang tebal dan keras dapat melindungi biji dari serangan organisme pengganggu tanaman. Tujuan penelitian ini adalah untuk mengamati karakteristik morfologi polong dari beberapa genotipe kedelai. Rancangan percobaan dalam penelitian ini adalah rancangan acak kelompok dengan tiga ulangan. Hasil sidik ragam menunjukkan bahwa panjang polong, lebar polong, tebal kulit polong, dan tebal biji terdapat perbedaan yang signifikan pada tiap genotipe sedangkan tebal polong, panjang biji dan lebar biji tidak ditemukan perbedaan yang signifikan. Genotipe MLGG 0892 memiliki ukuran tebal kulit polong paling tebal, sedangkan genotipe Brg/Myp-14 memiliki ukuran tebal kulit polong paling tipis. Polong dengan ukuran paling tebal dicapai oleh Brg/MLGG 0511-29, sedangkan paling tipis dicapai oleh MLGG 0892. Biji dengan ukuran paling tebal ada pada genotipe Anj/MLGG 051129 , biji dengan ukuran paling panjang diperoleh genotipe Anj/MLGG 0511-20, sedangkan biji dengan ukuran paling lebar adalah Grb/Lwt 17. Ketiga genotipe ini dinilai bagus karena memiliki ukuran tebal polong sekaligus tebal kulit polong yang cukup, juga menghasilkan biji dengan ukuran panjang, lebar, dan tebal lebih dari genotipe lainnya. Hasil uji korelasi menunjukkan ada hubungan yang signifikan antara panjang biji dengan lebar biji, dan panjang biji dengan tebal biji untuk tiap genotipe dari sepuluh genotip yang diamati.
\end{abstract}

Kata Kunci

Kedelai, Morfologi, Polong

\section{PENDAHULUAN}

Kedelai (Glycine max) merupakan jenis kacang polong daerah tropis yang dapat ditanam dan hidup di banyak jenis tanah pada berbagai kondisi iklim. Kedelai sebagai tanaman asli Asia timur dan awalnya tumbuh liar di China, Manchuria, Korea dan Jepang. Suhu optimal untuk pertumbuhan kedelai berkisar 20-30 ${ }^{\circ} \mathrm{C}$. Tanaman kedelai tumbuh tegak dan lebat dengan tinggi antara $60 \mathrm{~cm}$ dan $140 \mathrm{~cm}$, tergantung waktu tanam dan karakteristik varietas kedelai. Organ reproduksi kedelai yaitu bunga muncul di batang utama setiap simpul berkelompok berwarna putih, pink atau ungu. Pada umumnya produksi kedelai maksimal dan dapat dipanen setelah matang secara 
fisiologis saat daun berwarna kuning dan jatuh, dan setidaknya 95\% biji-bijiannya berwarna krem berwarna kuning dan keras [1].

Tanaman kedelai yang dibudidayakan (Glycine max L.) di Indonesia memiliki karakteristik antara lain merupakan tanaman semusim, tanaman tegak dengan tinggi antara $40 \mathrm{~cm}-90 \mathrm{~cm}$, bercabang, memiliki daun tunggal dan daun bertiga, bulu pada daun dan polong tidak terlalu padat dan umur tanaman antara $72-90$ hari. Kedelai hasil introduksi umumnya tidak memiliki percabangan atau sangat sedikit dan sebagian bertrikoma padat baik pada daun maupun polong [2]. Menurut Pitojo, secara morfologis, bagian-bagian bunga, buah, dan biji kedelai [3] dapat dideskripsikan sebagai berikut: pertama Bunga (Flos), akan muncul pada ketiak daun, tumbuh berkelompok pada ruas-ruas batang, berwarna putih atau ungu [4], memiliki kelamin jantan dan betina. Mulai berbunga pada umur tanman antara $30-50$ hari setelah tanam. Penyerbukan terjadi pada saat mahkota bunga masih menutup, sehingga kemungkinan terjadinya persilangan alami sangat kecil. Bunga akan rontok $\pm 60 \%$ sebelum membentuk polong [3]. Kedua Buah (Fructus) berupa polong, bertrikoma berwarna kuning kecoklatan atau abu-abu. Tiap tanaman menghasilkan $\pm 100-250$ polong, pada tanaman yang rapat hanya mampu dihasilkan 30 polong tiap tanaman. Polong muda berwarna hijau akan berubah selama proses pematangan menjadi kehitaman, keputihan atau kecoklatan saat polong tua. Bila polong telah kering mudah pecah mengeluarkan biji [3]. Polong (legumen) dibentuk dari satu daun buah, memiliki satu ruangan atau lebih dipisahkan oleh sekat-sekat semu. Bila polong tua dan matang, akan pecah menurut kampuhnya yaitu kampuh perut dan kampuh punggung, atau terpisah sepanjang sekat-sekat semunya. Karena adanya sekat-sekat semu, ruang polong terbagi atas beberapa bilik, berisi satu biji tiap biliknya [3]. Ketiga Biji (Semen) terletak di dalam polong, berjumlah $\pm 1-4$ biji, waktu muda berukuran kecil, berwarna putih kehijauan, dan lunak. Dalam perkembangannya biji semakin berisi hingga mencapai berat maksimal dan keras, keping dua, terbungkus oleh kulit tipis. Bentuk biji umumnya bulat lonjong, bundar atau bulat agak pipih. Warna kulit biji antara lain kuning, hitam, hijau, atau coklat. Embrio terdapat diantara keping biji, dengan hilum atau pusar biji melekat pada dinding buah [3].

Produk kedelai menjadi sumber protein yang baik bagi manusia, komposisi gizi dari kedelai terdiri dari minyak, karbohidrat dan mineral sebanyak $18 \%$, 35\% dan $5 \%$ yang dibutuhkan oleh tubuh manusia. Komposisi lemak dan protein menyusun $60 \%$ dari berat kacang kedelai, protein $40 \%$ dan lemak $20 \%$.

Komposisi gizi yang dimilikinya menjadikan kedelai menduduki urutan ketiga tanaman pangan penting di Indonesia setelah padi dan jagung, namun produksi kedelai selama ini belum mencukupi bahkan terdapat kecenderungan terus menurun dari tahun ke tahun sedangkan kebutuhan kedelai dalam negeri terus meningkat. Untuk memenuhi kebutuhan kedelai, Indonesia mengimpor kedelai secara terus menerus dengan jumlah yang meningkat dari tahun ke tahun [5]. Indonesia mengimpor kedelai sekitar 66,67\% pada tahun 2013 [6] karena hanya mampu memproduksi sebanyak 807.568 ton, sedangkan kebutuhan mencapai 2,5 juta ton per tahun. Tahun 2016 produksi kedelai Indonesia mencapai 886.000 ton biji kering sedangkan kebutuhan tahun 2016 sebesar 2,7 juta ton. Kondisi ini menunjukkan bahwa produksi dalam negeri belum mencukupi kebutuhan sehingga untuk memenuhi ketersediaan kedelai masih harus melakukan impor kedelai [7].

Sampai saat ini telah banyak dihasilkan varietas unggul oleh para peneliti, sebagai salah satu upaya yang dilakukan untuk memenuhi kebutuhan kedelai. Informasi 
tentang karakter morfologi yang dimiliki kedelai seperti polong dan biji termasuk bagian yang penting dalam perakitan varietas unggul. Suatu varietas kedelai dinilai unggul bila memiliki kelebihan atau keunggulan tertentu dibandingkan dengan varietas yang lain. Keunggulan tersebut dapat berupa ketahanan terhadap serangan hama dan penyakit, lingkungan, umurgenjah, hasil yang lebih tinggi dan sifat agronomi lainnya. Selama masa pengisian biji kedelai dipengaruhi oleh konsentrasi $\mathrm{CO}_{2}$ dan intesitas cahaya. Pati pada kulit polong merupakan cadangan makanan bagi pertumbuhan biji di bawah kondisi ketersediaan asimilat yang terbatas [8].

\section{METODE}

Lokasi penelitian di Instalasi Penelitian Aneka Kacang dan Umbi (INLITKABI) Jambegede, Kepanjen, Malang, Jawa Timur, Indonesia dan Laboratorium Biologi UM. Penelitian ini dilakukan dua tahap yaitu pertama penelitian lapangan dilakukan pada tanggal 21 April 2017 sampai 14 Juli 2017 dan kedua penelitian laboratorium pada tanggal 18 Juli 2017 hingga 25 Agustus 2017.

Bahan yang digunakan sebagai objek penelitian ini 10 tanaman kedelai yaitu (G1) Anj/MLGG 0511-20, (G2) Anj/MLGG 0511-29, (G3) Brg/MLGG 0511-29, (G4) Brg/Myp-14, (G5) Brg/Myp-3, (G6) Grb/Lwt-12, (G7) Grb/Lwt-17, (G8) Grb/Lwt-22,(G9) Grb/Myp-65, (G10) MLGG 0892, pestisida, pupuk $250 \mathrm{~kg}$ Phonska, $100 \mathrm{~kg}$ SP36 dan pupuk kandang $1 \mathrm{t} / \mathrm{ha}$. Penanaman dilakukan di petak sawah dengan jarak tanam $40 \mathrm{~cm} \times 15 \mathrm{~cm}$ pada luas plot 2, 24 $\mathrm{m}^{2}$.

Rancangan percobaan yang digunakan adalah rancangan acak kelompok dengan tiga ulangan bertujuan untuk mengamati karakteristik morfologi polong beberapa dari genotipe kedelai. Data hasil penelitian dianalisis menggunakan sidik ragam dilanjutkan uji korelasi untuk mengetahui hubungan antar variabel. Karakter morfologi polong yang diamati yaitu pertama panjang polong, diukur dengan mengukur panjang polong kedelai dengan menggunakan jangka sorong, kedua lebar polong, diukur dengan mengukur lebar polong kedelai dengan menggunakan jangka sorong, ketiga tebal polong, diukur dengan mengukur tebal polong kedelai dengan menggunakan jangka sorong, keempat ketebalan kulit polong, diukur menggunakan mikrometer dengan mengukur kulit polong kiri dan kanan, kelima panjang biji, diukur menggunakan jangka sorong dengan mengukur biji mulai dari pangkal sampai ujung biji, keenam lebar biji, diukur dengan menggunakan jangka sorong dengan mengukur lebar sisi biji, ketujuh tebal biji, diukur dengan mengukur tebal biji kedelai dengan menggunakan jangka sorong.

\section{HASIL DAN PEMBAHASAN}

Hasil penelitian menunjukkan bahwa karakter morfologi polong sepuluh genotipe kedelai yang diamati bervariasi untuk ukuran panjang, lebar, dan tebal polong serta tebal kulit polong. Demikian pula untuk panjang, lebar, dan tebal biji tiap genotipnya. Dari hasil analisis menggunakan sidik ragam untuk tujuh karakter morfologi polong kedelai pada Tabel 1. Diketahui bahwa panjang polong, lebar polong, tebal kulit polong, dan tebal biji terdapat perbedaan yang signifikan pada taraf $1 \%$ sedangkan tebal polong, panjang biji dan lebar biji tidak terdapat perbedaan signifikan. 
Tabel 1. Hasil anova pada karakter morfologi polong sepuluh genotipe kedelai

\begin{tabular}{ccc}
\hline Parameter & KT genotipe & KT error \\
\hline Panjang polong & $39,679^{* *}$ & 38,355 \\
\hline Lebar polong & $0,015^{* *}$ & 0,006 \\
\hline Tebal polong & 0,000 & 0,002 \\
\hline Tebal kulit polong & $0,16^{* *}$ & 0,010 \\
\hline Panjang biji & 0,001 & 0,001 \\
\hline Lebar biji & 1,476 & 1,706 \\
\hline Tebal biji & $0,009^{* *}$ & 0,005
\end{tabular}

Keterangan: $\left({ }^{*}\right)$ nyata pada taraf $5 \% ;\left(^{* *}\right)$ nyata pada taraf $1 \%$

Tabel 2 menunjukkan bahwa nilai koefisien keragaman dengan angka terbesar terdapat pada karakter morfologi tebal polong yaitu $0,978 \%$, sedangkan nilai koefisien keragaman dengan angka terkecil yaitu 0, 091\% terdapat pada karakter morfologi lebar polong. Hal ini dapat dipahami bahwa tingkat keragaman tebal polong pada setiap genotipe lebih tinggi dibandingkan karakter lainnya, sedangkan tingkat keragaman lebar polong pada setiap genotip lebih rendah dibandingkan dengan karakter lainnya.

Tabel 2 Hasil nilai rata-rata, kisaran, standar deviasi, dan koefisien keragaman morfologi sepuluh genotipe kedelai

\begin{tabular}{ccccc}
\hline Karakter Morfologi & Rata-Rata & Range & $\begin{array}{c}\text { Standar } \\
\text { deviasi }\end{array}$ & Koefisien Keragaman (\%) \\
\hline Panjang polong $(\mathrm{cm})$ & 3,8864 & $3,65-4,34$ & 0,18418 & 0,369 \\
\hline Lebar polong $(\mathrm{cm})$ & 0,8280 & $0,74-0,93$ & 0,05777 & 0,091 \\
\hline Tebal polong $(\mathrm{cm})$ & 0,4958 & $0,47-0,53$ & 0,01806 & 0,978 \\
\hline Tebal kulit polong $(\mathrm{mm})$ & 0,3585 & $0,24-0,48$ & 0,07138 & 0,218 \\
\hline Panjang biji $(\mathrm{cm})$ & 0,6691 & $0,64-0,69$ & 0,01602 & 0,385 \\
\hline Lebar Biji $(\mathrm{cm})$ & 0,5622 & $0,53-0,59$ & 0,01837 & 0,432 \\
\hline Tebal Biji $(\mathrm{cm})$ & 0,4219 & $0,31-0,46$ & 0,04350 & 0,218 \\
\hline
\end{tabular}

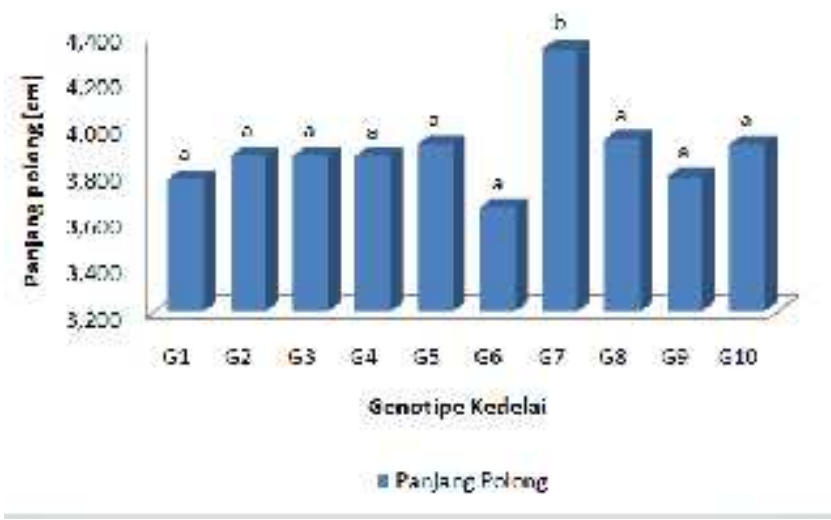

Gambar 1 Panjang Polong Kedelai pada Berbagai Perlakuan

Polong dengan ukuran terpanjang terdapat pada genotipe Grb/Lwt-17 sedangkan terpendek dimiliki genotipe Grb/Lwt-12 seperti ditunjukkan Gambar 1. Ukuran dan bentuk polong menjadi maksimal pada saat awal periode pemasakan biji [9]. Ukuran panjang polong \pm $2-7 \mathrm{~cm}$ dengan bentuk berlekuk lurus atau ramping berisi $1-5$ biji [10]. 


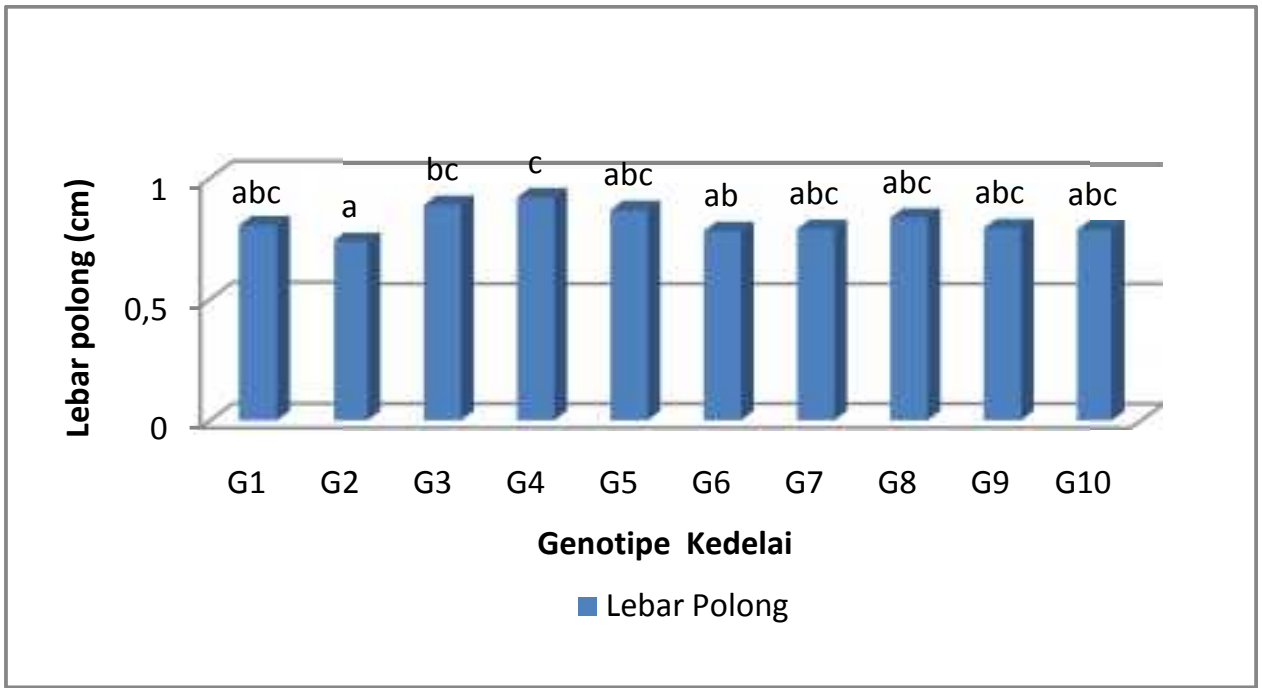

Gambar 2 Lebar Polong pada Berbagai Perlakuan

Polong dengan ukuran paling lebar berada pada genotipe Brg/Myp-14 sedangkan ukuran polong yang lebarnya paling kecil dimiliki genotipe Anj/MLGG 0511-29 seperti ditunjukkan Gambar 2. Pembentukan polong kedelai seiring dengan pertambahan umur serta jumlah bunga yang terbentuk. Polong kedelai dibentuk sekitar 7-10 hari setelah bunga pertama muncul. Pembentukan polong dan pembesaran biji akan semakin cepat terjadi setelah proses pembentukan bunga berhenti [9]. Lebar polong kedelai maksimum setelah mencapai umur 30 hari setelah tanaman kedelai berbunga [10].

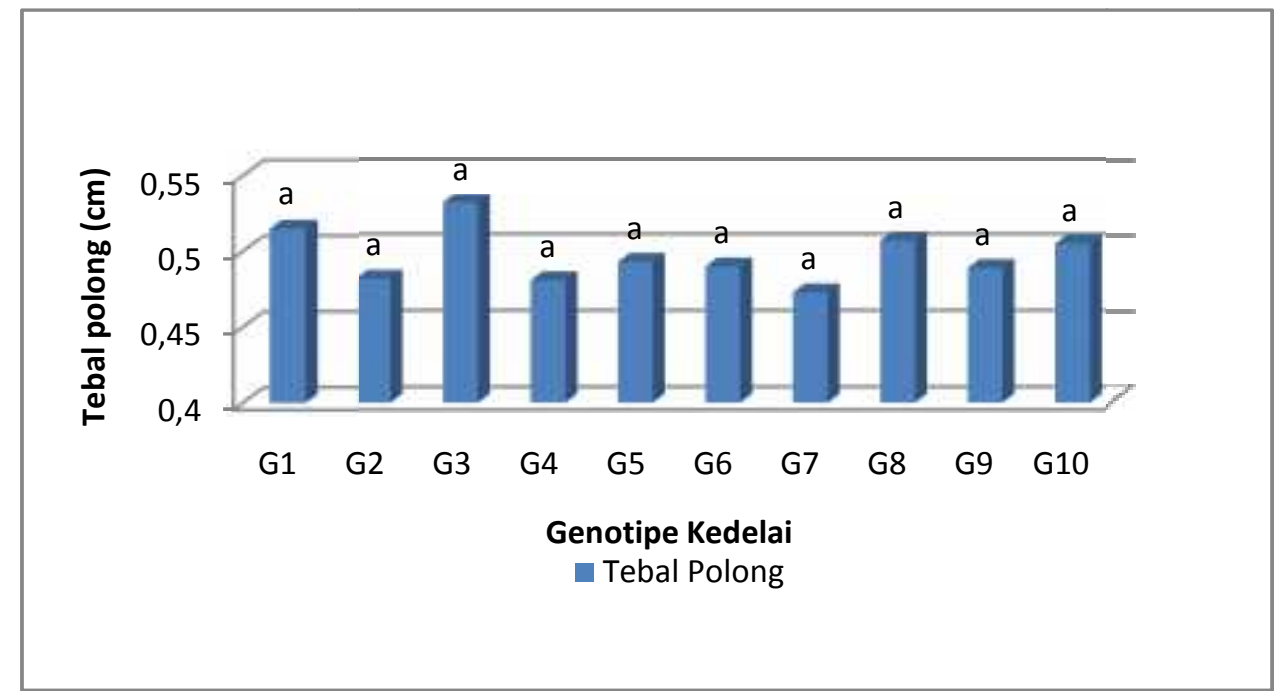

Gambar 3 Tebal Polong pada Berbagai Perlakuan

Polong dengan ukuran paling tebal dicapai oleh Brg/MLGG 0511-29, sedangkan paling tipis ada pada genotipe Grb/Lwt 17. Jumlah polong yang terbentuk pada setiap ketiak tangkai daun sangat beragam, antara 1-10 buah untuk tiap kelompok. Pada tiap tanaman kedelai, jumlah polong dapat mencapai lebih dari 50 buah, bahkan ratusan buah [9]. 


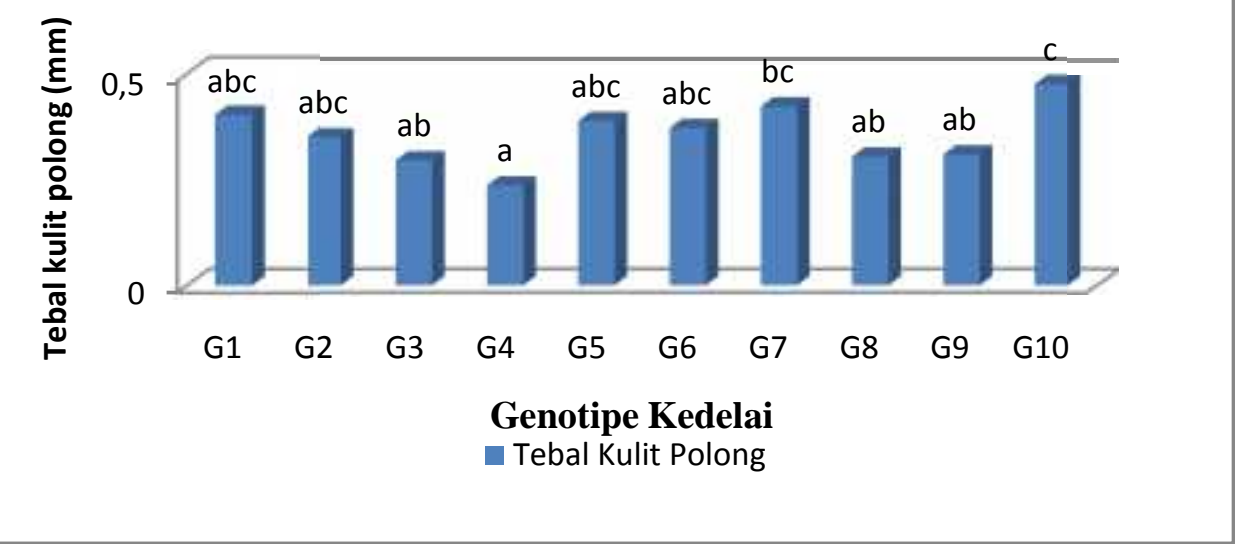

Gambar 4 Tebal Polong pada Berbagai Perlakuan

Genotipe MLGG 0892 memiliki ukuran tebal kulit polong paling tebal, sedangkan genotipe Brg/Myp-14 memiliki ukuran tebal kulit polong paling tipis. Ketebalan kulit polong kedelai mempunyai hubungan yang kuat dengan intensitas serangan hama. Semakin besar ukuran tebal kulit polong, maka intensitas serangan hama semakin kecil [11].

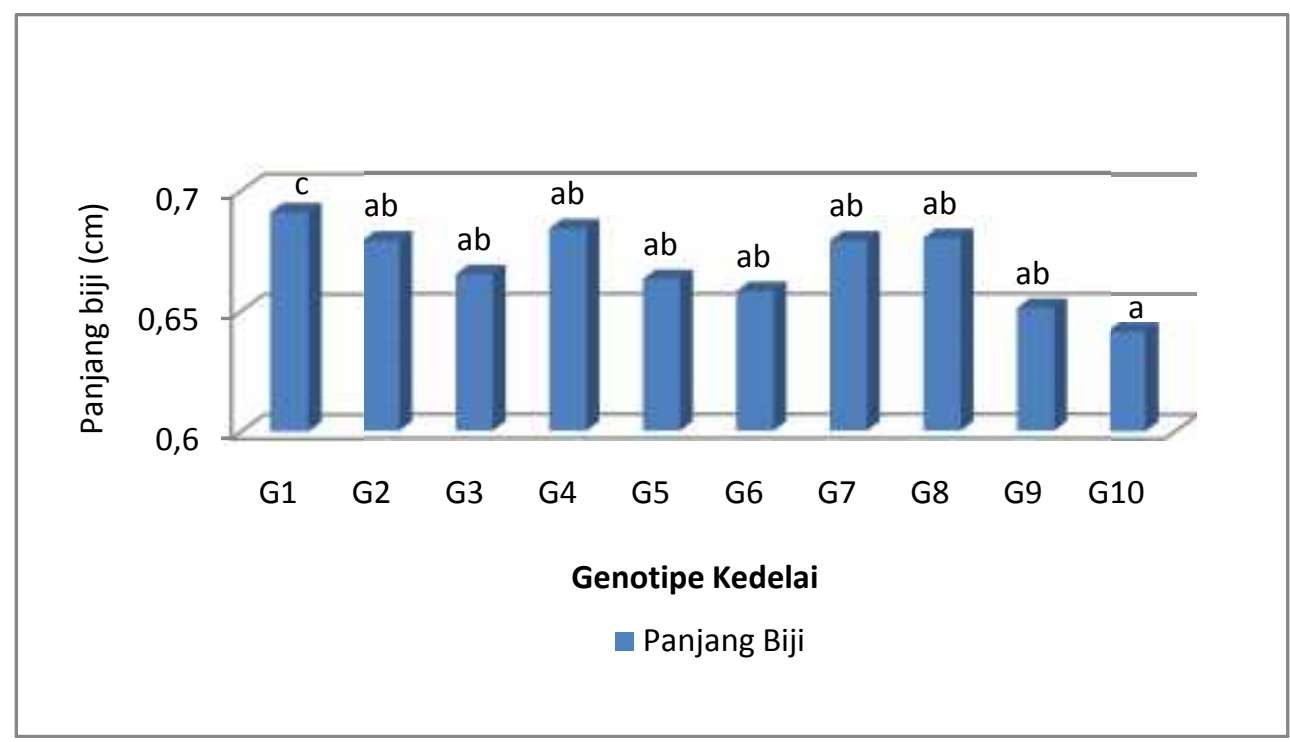

\section{Gambar 5 Panjang Polong pada Berbagai Perlakuan}

Genotipe Anj/MLGG 0511-20 memiliki ukuran panjang biji paling tinggi, sedangkan biji dengan ukuran paling rendah ada pada genotipe MLGG 0892. Tahapan pengisian biji dan polong hingga penuh - tahapan reproduksi sebagai berikut $R-5$, awal benih-benih adalah $1 / 8$ inci panjang $(3 \mathrm{~mm})$ di polong pada salah satu dari empat nodus teratas pada batang utama; R-6, unggulan penuh mengandung biji hijau yang memenuhi kapasitas polong disalah satu dari empat nodus paling atas batang utama; R-7, kematangan awal - satu polong normal dibagian utama, batang telah mencapai warna polong yang matang; R-8, kematangan penuh- $95 \%$ polong telah mencapai warna matang [12]. 


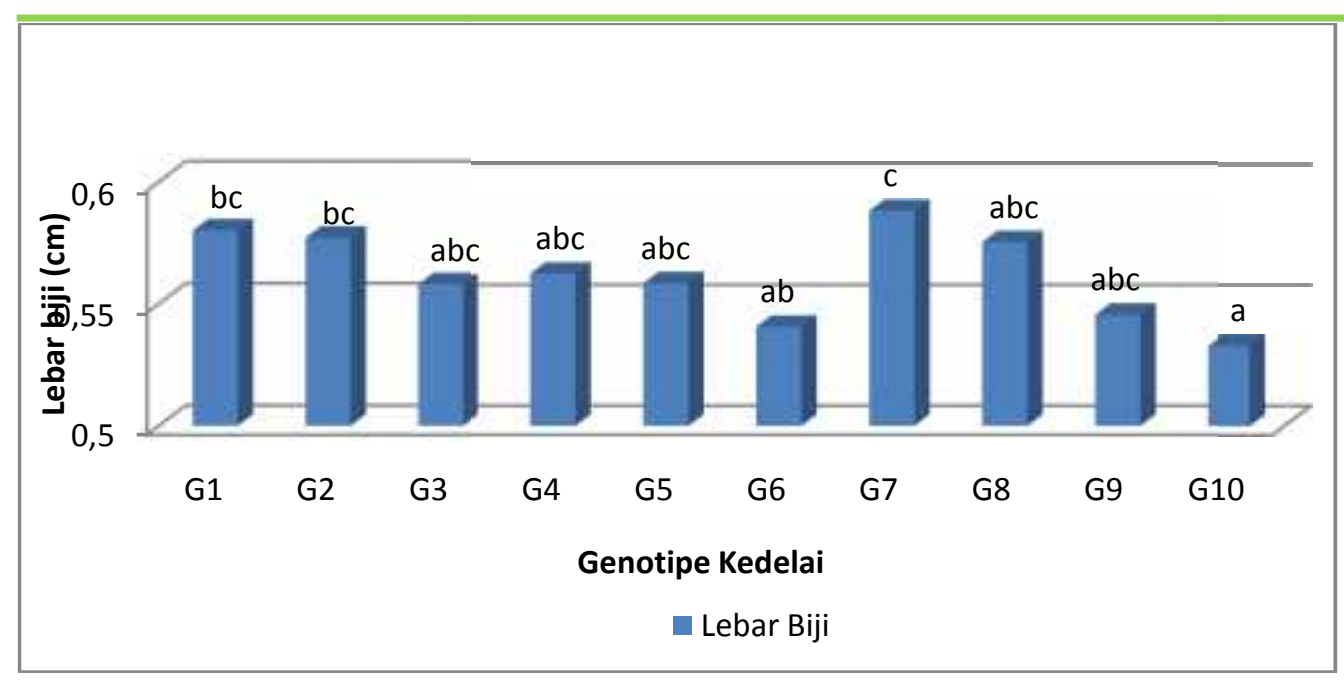

Gambar 6 Lebar Biji pada Berbagai Perlakuan

Biji dengan ukuran paling lebar ada pada genotipe Grb/Lwt 17, sedangkan ukuran lebar biji terkecil terdapat pada genotipe MLGG092. Setiap biji kedelai mempunyai ukuran bervariasi, mulai dari kecil (sekitar 7- $9 \mathrm{~g} / 100 \mathrm{biji}$ ), sedang (10-13 g/100 biji), dan besar (>13 g/100 biji). Bentuk biji bervariasi, tergantung pada varietas tanaman, yaitu bulat, agak gepeng, dan bulat telur [9].

Biji dengan ukuran paling tebal ada pada genotipe Anj/MLGG 0511-29, sedangkan biji dengan ukuran paling tipis ditemukan pada genotipe Grb/Myp-65. Sebagian besar biji berbentuk bulat telur. Biji kedelai terbagi menjadi dua bagian utama, yaitu kulit biji dan embrio. Pada kulit biji terdapat bagian yang disebut pusar (hilum) yang berwarna coklat, hitam, atau putih. Pada ujung hilum terdapat mikrofil, berupa lubang kecil yang terbentuk pada saat proses pembentukan biji. Warna kulit biji bervariasi, mulai dari kuning, hijau, coklat, hitam, atau kombinasi campuran dari warna-warna tersebut. Biji kedelai tidak mengalami masa dormansi sehingga setelah proses pembijian selesai, biji kedelai dapat langsung ditanam. Namun demikian, biji tersebut harus mempunyai kadar air berkisar 12-13\% [9].

Tabel 3. Hasil Uji Korelasi

\begin{tabular}{|c|c|c|c|c|c|c|c|}
\hline & & Lebar_Polong & $\begin{array}{c}\text { Tebal_Polon } \\
\mathrm{g}\end{array}$ & $\begin{array}{c}\text { Tebal_Kulit_Pol } \\
\text { ong }\end{array}$ & Panjang_Biji & Lebar_Biji & Tebal_Biji \\
\hline Panjang_Polong & $\begin{array}{l}\text { Pearson } \\
\text { Correlation }\end{array}$ & 0.095 & -0.282 & 0.267 & 0.161 & 0.390 & 0.271 \\
\hline Lebar_Polong & $\begin{array}{l}\text { Pearson } \\
\text { Correlation }\end{array}$ & & 0.281 & -0.589 & 0.156 & -0.071 & 0.103 \\
\hline Tebal_Polong & $\begin{array}{l}\text { Pearson } \\
\text { Correlation }\end{array}$ & & & -0.020 & -0.072 & -0.132 & 0.175 \\
\hline $\begin{array}{l}\text { Tebal_Kulit_Pol } \\
\text { ong }\end{array}$ & $\begin{array}{l}\text { Pearson } \\
\text { Correlation }\end{array}$ & & & & -0.334 & -0.096 & 0.111 \\
\hline Panjang_Biji & $\begin{array}{l}\text { Pearson } \\
\text { Correlation }\end{array}$ & & & & & $0.930 * *$ & $0.634 *$ \\
\hline Lebar_Biji & $\begin{array}{l}\text { Pearson } \\
\text { Correlation }\end{array}$ & & & & & & 0.616 \\
\hline
\end{tabular}


Ketiga genotipe yaitu Anj/MLGG 0511-29, Anj/MLGG 0511-20, dan Grb/Lwt 17 dinilai bagus karena memiliki ukuran tebal polong sekaligus tebal kulit polong yang cukup, juga menghasilkan biji dengan ukuran panjang, lebar, dan tebal lebih dari genotipe lainnya.

Perubahan pada satu variabel bila dapat ditunjukkan berkaitan dengan perubahan pada variabel lain, maka kedua variabel itu dapat dikatakan berkorelasi [12]. Pada tabel 3, terdapat hubungan yang signifikan antara panjang biji dengan lebar biji $(r=0,001)$, dan panjang biji dengan tebal biji $(r=0,049)$ untuk tiap genotipe dari sepuluh genotip yang diamati.

\section{SIMPULAN}

Hasil analisis karakteristik morfologi polong sepuluh genotipe kedelai yaitu Anj/MLGG 051120, Anj/MLGG 0511-29, Brg/MLGG 0511-29, Brg/Myp-14, Brg/Myp-3, Grb/Lwt-12, Grb/Lwt17, Grb/Lwt-22, Grb/Myp-65, dan MLGG 0892 menunjukkan bahwa ada perbedaan untuk ukuran panjang, lebar, dan tebal polong serta tebal kulit polong demikian pula untuk panjang, lebar, dan tebal biji tiap genotipnya. Dari hasil analisis sidik ragam untuk tujuh karakter morfologi polong kedelai diketahui bahwa panjang polong, lebar polong, tebal kulit polong, dan tebal biji terdapat perbedaan yang signifikan pada taraf $1 \%$ yaitu 39,$679 ; 0,015 ; 0,16$; 0,009 sedangkan tebal polong, panjang biji dan lebar biji tidak terdapat perbedaan signifikan. Demikian pun untuk nilai koefisien keragaman dengan angka terbesar terdapat pada karakter morfologi tebal polong yaitu $0,978 \%$, sedangkan nilai koefisien keragaman dengan angka terkecil yaitu 0, 091\% terdapat pada karakter morfologi lebar polong. Hal ini dapat dipahami bahwa tingkat keragaman tebal polong pada setiap genotipe lebih tinggi dibandingkan karakter lainnya, sedangkan tingkat keragaman lebar polong pada setiap genotip lebih rendah dibandingkan dengan karakter lainnya. Berdasarkan hasil uji korelasi juga dapat diketahui terdapat hubungan yang signifikan antara panjang biji dengan lebar biji $(r=0,001)$, dan panjang biji dengan tebal biji $(r=0,049)$ untuk tiap genotipe dari sepuluh genotip yang diamati.

\section{SARAN}

Berdasarkan karakterisasi morfologi polong dari penelitian ini dapat menjadi acuan perakitan varietas unggul untuk penelitian selanjutnya sehingga diharapkan menghasilkan genotipegenotipe yang unggul tahan terhadap serangan hama.

\section{UCAPAN TERIMA KASIH}

Kepada segenap pimpinan dan staf Instalasi Penelitian Aneka Kacang dan Umbi (INLITKABI) Jambegede, Kepanjen, Malang, Jawa Timur, Indonesia dan Laboratorium Biologi UM. Balai Penelitian Tanaman Aneka Kacang dan Umbi (BALITKABI) Malang serta Kebun Percobaan Instalasi Penelitian Tanaman aneka Kacang dan Umbi (Inlitkabi) Kepanjen, Kabupaten Malang yang telah memberikan izin pada penulis untuk melakukan penelitian, penulis mengucapkan terima kasih. Penulis juga mengucapkan terima kasih untuk teman-teman mahasiswa pascasarjana prodi Biologi FMIPA 
Universitas Negeri Malang yang telah bekerjasama sebagai Tim Kedelai 2016 selama penelitian berlangsung, serta semua pihak yang telah mengulurkan tangan untuk memberikan bantuan.

\section{DAFTAR RUJUKAN}

[1] ACIAR, 2011. Soybean. Blue Star Print. Canberra.

[2] Adie, M.M. dan Krisnawati, A. 2010. Biologi Tanaman Kedelai. Malang: Balai Penelitian Tanaman Kacang-Kacangan dan Umbi-Umbian.

[3] Pitojo. S, 2003. Benih Kedelai. Kanisius. Yogyakarta. $84 \mathrm{hlm}$.

[4] Irwan-SZ-P.Heru. 2016. Tanggap Galur-Galur kedelai Dan Dua Varietas Unggul Terhadap CpMMVBioedukasi, diakses 29 Nopember 2016.

[5] Rusono, dkk. 2013. Studi Pendahuluan: Rencana Pembangunan jangka Menengah Nasional (RPJMN) Bidang Pangan dan Pertanian 2015-2019. Jakarta: Direktorat Pangan dan Pertanian, Bappenas.

[6] [AMIS] Agricultural Market Information System, 2015. Indonesia-Soybean at a Glance. http://www.fao.org. [6 Maret 2015], diakses 4 Oktober 2017

[7] LAKIN DJTP, 2016. Laporan Kinerja Dirjen Tanaman Pangan 2016. Kementrian Pertanian RI. Jakarta

[8] Fader dan Koller. 1985. Seed growth rate and carbohydrate pool sizes of the soybean fruit. Plant Physiol. 79(3):663-6. US. Diakses 16 Oktober 2017.

[9] Adisarwanto, T, 2005. Budidaya Dengan Pemupukan Yang Efektif dan Pengoptimalan Peran Bintil Akar Kedelai. Penebar Swadaya: Bogor.

[10] Adie, M.M. dan Krisnawati, A. 2010. Biologi Tanaman Kedelai. Malang: Balai Penelitian Tanaman Kacang-Kacangan dan Umbi-Umbian.

[11] Sarjan, M. dan Sab'I., I. 2014. Karakteristik Polong Kedelai Varietas Unggul Yang Terserang Hama Penghisap Polong (Riptortus linearis) Pada Kondisi Cekaman Kekeringan. Jurnal Lahan Suboptimal $3(2)$.

[12] Sulisetijono. 2013. Handout Statistika. UM: Malang 